\title{
TINDAK TUTUR DIREKTIF PEMBINA UPACARA DI SMA NEGERI 2 MERLUNG KABUPATEN TANJUNG JABUNG BARAT
}

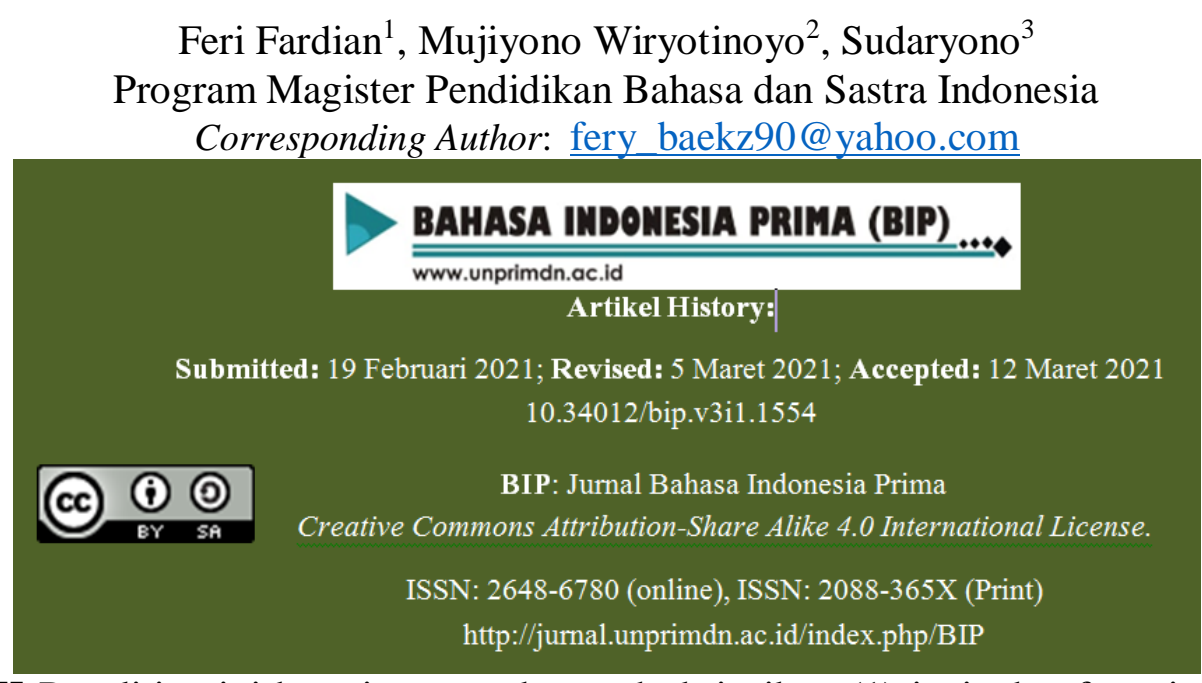

ABSTRAK-Penelitian ini bertujuan untuk mendeskripsikan (1) jenis dan fungsi tindak tutur direktif yang digunakan pembina upacara dalam menyampaikan amanat, dan (2) penerapan strategi tindak tutur direktif oleh pembina upacara dalam menyampaikan amanat. Hasil temuan dalam kegiatan upacara di SMA Negeri 2 Merlung menunjukkan bahwa terdapat 6 jenis dan 11 fungsi tuturan direktif, dimana penggunaan jenis nasihat dan fungsi menasehati lebih banyak digunakan, apabila dibandingkan dengan penggunaan jenis dan fungsi tindak tutur direktif yang lain. Sementara untuk penerepan strategi tindak tutur direktif, strategi bertutur terus terang dengan basa basi kesantunan negatif adalah yang paling sering digunakan guru (penutur). Merujuk pada temuan hasil penelitian dapat disimpulkan bahwa: (1) tindak tutur direktif yang cenderungdilakukan guru dalam kegiatan upacara di SMA Negeri 2 Merlung adalah jenis tindak tutur nasihat, (2) strategi bertutur terus terang dengan basa-basi kesantunan negatif adalah yang paling sering digunakan guru (penutur) dalam kegiatan upacara. Berdasarkan hasil dan kesimpulan yang diperoleh, maka disarankan perlunya penggunaan bentuk tindak tutur direktf yang bervariasi dan strategi yang dapat memunculkan perasaan positif pada siswa (mitra tutur).

Kata kunci: pragmatik, tindak tutur, direktif, jenis direktif. fungsi direktif, pembina upacara

ABSTRACT-This study aims to describe (1) the type and function of directive speech acts used by the head of ceremony in delivering the mandate, and (2) the application of the directive speech act strategy by the head of ceremony in delivering the mandate. The findings in the ceremonial activities at the State of Merlung $2^{\text {th }}$ Senior High School showed that there were 6 types and 11 directive speech functions, where the use of the type of advice and the advising function was more widely used, when compared to the use of other types and directive speech acts. Meanwhile, for the forerunners of directive speech act strategies, frank speaking strategies with negative politeness bases are the most frequently used by teachers (speakers). Referring to the findings of the research, it can be concluded that: (1) the directive speech acts that teachers tend to do in the ceremonial activities at the State of Merlung $2^{\text {th }}$ Senior High School are types of advice speech acts, (2) the strategy of speaking frankly with small talk of negative politeness is the most frequently used teacher (speaker) in ceremonial activities. Based on the results and conclusions obtained, it is suggested the use of various forms of speech acts by directors \& strategies that can generate positive feelings in students (speech partners).

Key words: pragmatic, acts of said, directive, type of directive. function of directive, head of ceremony 


\section{A. Pendahuluan}

Bahasa merupakan alat komunikasi langsung maupun tidak langsung antar individu yang bertujuan untuk menyampaikan maksud dan tujuan. Mengingat pentingnya bahasa sebagai alat komunikasi dan memperhatikan wujud bahasa itu sendiri, kita dapat membatasi pengertian bahasa sebagai: "alat komunikasi antara anggota masyarakat berupa simbol bunyi yang dihasilkan oleh alat ucap manusia" (Keraf, 2004:1). Dengan adanya fungsi bahasa sebagai alat komunikasi diharapkan manusia mahir dalam berbahasa, baik dalam bahasa tulis maupun bahasa lisan, agar mereka yang mendengar atau diajak bicara dengan mudah dapat memahami apa yang dimaksudkan.

Bahasa yang digunakan untuk berkomunikasi pada dasarnya memiliki maksud agar apa yang disampaikan oleh penutur dapat diterima dan dimengerti dengan baik oleh penerima tuturan. Penyampaian informasi tidak hanya terjadi di sekitar lingkungan masyarakat, seperti contohnya rumah, tetapi juga di sekolah yang merupakan satu dari sekian tempat utama dimana seseorang belajar untuk bisa memahami pembelajaran tentang nilainilai yang terkandung dalam sebuah informasi yang dituturkan.

Kegiatan upacara merupakan kegiatan yang dilakukan disetiap sekolah pada hari senin di halaman sekolah untuk mengibarkan bendera Sang Sakka Merah Putih. Kegiatan upacara ini bertujuan untuk melatih kedisiplinan siswa serta memupuk rasa cinta tanah air dan bangsa ataupun menumbuhkan semangat jiwa nasionalisme. Dalam kegiatan upacara memiliki acara pokok yaitu pemberian amanat oleh guru sebagai pembina upacara untuk semua peserta upacara. Amanat yang diberikan berisikan nilai-nilai moral yang patut dijadikan teladan. Maksud dari amanat tersebut yaitu memberikan pengarahan serta informasi kepada semua peserta upacara, serta memotivasi siswa atau memberikan dorongan-dorongan kepada siswa kepada hal-hal yang positif.

Peran guru sebagai pembina upacara terutama pemberian amanat di dalam pidatonya, seharusnya dapat menjadi contoh bagi peserta didik dalam menguasai keterampilan berbahasa seperti keterampilan berbicara, dengan kemampuan berbicara yang baik seorang pembina upacara menjadi sosok yang dirindukan oleh peserta didik. Namun seringkali perbedaan latar belakang, kebudayaan, dan juga dialek dari guru ketika berpidato sebagai pembina upacara, mengakibatkan berbeda pula cara penyampaian suatu tuturan sehingga apa yang disampaikan tidak dapat diterima terlebih lagi untuk bisa dipahami secara benar oleh siswa-siswinya.

Kesantunan berbahasa sangat penting peranannya untuk berkomunikasi dalam kehidupan sosial kemasyarakatan. Tindak tutur kesantunan berbahasa harus dilakukan oleh semua pihak untuk menjaga kualitas pergaulan baik di dunia kerja maupun di dunia sosial masyarakat (Saefudin, 2017). Oleh karena itu, sebagai pembina upacara sebaiknya guru memahami nilai-nilai kesantunan berbahasa dalam menyampaikan amanat, agar pesan-pesan moral yang disampaikan dapat diterima dan dipahami dengan baik oleh siswa-siswinya. Hal ini dikarenakan bahasa dan tutur kata adalah salah satu faktor penting dalam keberhasilan memberikan amanat.

Suatu proses komunikasi berbahasa lewat ujaran seperti halnya nasehat yang diberikan tokoh agama kepada remaja, tidak terlepas dari adanya tindak tutur atau peristiwa tutur (Sulistyowati, 2013).Tindak tutur adalah berlangsungnya interaksi linguistik dalam satu bentuk ujaran atau lebih yang melibatkan dua pihak, yaitu penutur atau lawan tutur dengan satu pokok tuturan dalam waktu, tempat, dan situasi tertentu (Chaer danAgustina, 2010). Di dalam ilmu pragmatis terdapat tiga jenis tindakan yang dapat diwujudkan oleh seorang penutur, yakni tindak lokusi 
(locutionary act), tindak ilokusi (illocutionary act), dan tindak perlokusi (perlucotionary act) (I Dewa Putu Wijana, 1996). Penelitian ini mengkaji bentuk tindak tutur ilokusi khususnya tuturan direktif pada tuturan guru sebagai pembina upacara dalam menyampaikan amanat pada kegiatan upacara di SMA Negeri 2 Merlung. Tindak tutur ilokusi merupakan tindak tutur yang mengandung maksud berkaitan dengan bertutur kepada siapa, kapan, dan di mana tindak tutur itu dilakukan. Tindak tutur ilokusi diklasifikasikan menjadi lima kategori, yaitu asertif, direktif, komisif, ekspresif, dan deklarasi (Leech, 1993).

SMA Negeri 2 Merlung sebagai salah satu sekolah yang juga diminati oleh siswa lulusan dari Sekolah Menengah Pertama, memiliki beragam jenis sifat dan karakter siswa-siswi yang berbeda-beda antara satu sama lainnya. Tidak semua dari mereka mau mendengarkan apa yang diperintahkan apabila tidak disampaikan sesuai dengan apa yang mereka anggap santun dan tidak merendahkan mereka selaku siswa-siswi.

Hasil temuan terkait respon siswa terhadap tuturan amanat pembina upacara dalam pidato yang disampaikan di kegiatan upacara SMA Negeri 2 Merlung, menunjukkan bahwa seringkali para guru (pembina upacara) yang merasa bisa menegur siswa-siswi yang dianggap melakukan pelanggaran, menyampaikan maksud baiknya dengan kalimat perintah yang penggunaan bahasanya kurang bisa diterima oleh siswa-siswi yang mendengarkan karena dirasa kurang santun dalam penyampaiannya, keadaan seperti ini justru mengakibatkan terjadinya pengabaian dan pembangkangan dari apa yang disampaikan oleh Pembina Upacara ketika menyampaikannya dalam pidato senin pagi yang berisikan kalimat imperatif atau kalimat perintah tadi. Sehingga pesan yang disampaikan tidak akan bisa terlaksana karena tidak adanya respon atau tanggapan yang baik dari siswa-siswi selaku penerima tuturan yang mendengarkan pidato Pembina Upacara selaku penutur.

Kondisi demikian terjadi dikarenakan siswa-siswi pada dasarnya juga berasal dari latar belakang keluarga dan kebudayaan yang berbeda-beda, mengakibatkan berbeda pula cara dalam menerima tuturan yang disampaikan.Oleh karena itu, keterampilan guru dalam tindak tutur direktif khususnya cara guru memilih bentuk dan strategi yang digunakan saat bertutur sangat penting untuk dikuasai. Hal ini dikarenakan pemilihan strategi dan bentuk tindak tutur direktif tersebut akan berpengaruh terhadap cara guru bertutur dan otomatis juga berpengaruh terhadap tanggapan atau respons siswa.

Alasan yang mendasari penelitian ini dilakukan karena dalam menyampaikan sebuah amanat, seorang guru memiliki karakteristik yang berbeda-beda. Sebuah amanat yang disampaikan guru terdapat kesantunan-kesantunan direktif seorang guru dalam berpidato. Kesantunankesantunan direktif tersebut berfungsi sebagai penegas agar seseorang melakukan tindakan. Untuk itu diperlukan suatu kajian untuk mengetahui berbagai bentuk tindak tutur direktif beserta penggunaan fungsi direktif agar didapatkan suatu strategi bertutur yang baik bagi guru SMA Negeri 2 Merlung dalam menyampaikan amanat kepada siswa-siswinya.

Penelitian ini bertujuan untuk memaparkan penerapan strategi tindak tutur direktif serta jenis tindak tutur direktif yang digunakan pembina upacara dalam menyampaikan amanat di SMA Negeri 2 Merlung Kab. Tanjung Jabung Barat.

\section{B. Metode Penelitian}

Penelitian ini termasuk ke dalam jenis penelitian pragmatik yang bertujuan untuk mengungkapkan seluk beluk tindak tutur direktif Pembina Upacara SMA Negeri 2 Merlung Kab. Tanjung Jabung Barat. Adapun pendekatan yang digunakan dalam penelitian ini adalah pendekatan kualitatif. 
Narasumber yang digunakan sebagai sumber informasi sekaligus subjek dalam penelitian ini adalah guru SMA Negeri 2 Merlung Kab. Tanjung Jabung Barat yang bertindak sebagai pembina upacara dalam kegiatan upacara hari senin.

Data dalam penelitian ini diperoleh dengan menggunakan teknik simak bebas libat cakap (SBLC), yang dilakukan pada saat pidato pembina upacara berlangsung. Adapun jenis data yang digunakan dalam penelitian ini termasuk ke dalam data kualitatif berupa kalimat tuturan direktif yang diucapkan oleh guru SMA Negeri 2 Merlung selaku pembina upacara (penutur). Data yang diperoleh kemudian dianalisis dengan menggunakan teknik analisis padan pragmatik dan klasifikasi.

\section{Hasil dan Pembahasan}

\section{a. Hasil Penelitian}

Hasil analisis data tindak tutur direktif yang digunakan oleh guru SMA Negeri 2 Merlung Kab. Tanjung Jabung Barat, didapatkan enam jenis tindak tutur direktif, yaitu; permintaan (requstives), pertanyaan (questions), perintah (requirements), larangan (prohibitive), pemberian izin (permissives), dan nasihat (advisories).

\section{1) Permintaan (requstives)}

Tindak tutur permintaan (requstives)menunjukkan bahwa dalam mengucapkan sesuatu tuturan, penutur meminta kepada mitra tutur untuk melakukan suatu perbuatan. Penutur mengekspresikan keinginan dan maksud agar mitra tutur melakukan tindakan atas keinginan penutur. Dari hasil analisis jenis tuturan ini terdapat tujuh fungsi tuturan permintaan yang digunakan oleh pembina upacara, yaitu; fungsi mengajak dan berdoa, fungsi berdoa, fungsi berdoa dan menuntut, fungsi menekan, fungsi memohon, fungsi meminta dan mengarahkan, dan fungsi berdoa dan membolehkan. Diantara ketujuh fungsi tersebut, fungsi berdoa adalah tuturan permintaan yang paling sering digunakan oleh guru, yaitu sebanyak 7 tuturan.
Tindak tutur requstives dapat dilihat pada tuturan berikut: "Selanjutnya shalawat beserta salam kita panjatkan kepada nabi besar Muhammad SAW, yang selalu kita nantikan syafaatnya di akhirat nanti. Amin Ya Robbal Alamin." Tuturan tersebut mengandung maksud bahwa guru (pembina upacara) meminta kepada seluruh peserta upacara untuk bershalawat kepada nabi besar mereka. Tuturan ini juga mengekspresikan keinginan penutur agar mitra tutur (peserta upacara) turut serta bershalawat kepada nabi besar Muhammad SAW. Jika penutur menyikapi permintaan dengan ekspresi sungguh-sungguh atau mengharapkan tuturannya dipatuhi, maka mitra tutur diharapkan segera melaksanakan apa yang diinginkan oleh penutur.

\section{2) Pertanyaan (questions)}

Tindak tutur bertanya (questions) mengandung pengertian bahwa penutur memohon kepada mitra tutur agar memberikan informasi tertentu. Berdasarkan ciri formalnya pola intonasi kalimat tanya ditandai dengan tanda (?). Ciri lain yang menandai kalimat tanya adalah penggunaan kata tanya seperti: apa, siapa, dimana, kapan, mengapa dan bagaimana.Dari hasil analisis jenis tuturan initerdapat tiga fungsi tuturan pertanyaan yang digunakan oleh pembina upacara, yaitu; fungsi pertanyaan retoris, fungsi bertanya, dan fungsi bertanya dan menuntut. Diantara ketiga fungsi tersebut, fungsi bertanya adalah tuturan pertanyaan yang paling sering digunakan oleh guru, yaitu sebanyak 5 tuturan.

Tindak tutur questions dapat dilihat pada tuturan berikut: "Apakah bisa dimengerti yang perempuan?". Tuturan tersebut mengekspresikan pertanyaan untuk meyakinkan bahwa amanat yang telah diberikan dapat dimengerti oleh siswi perempuan. Tuturan ini ditandai dengan kata "apakah", yang hanya memerlukan jawaban ya atau tidak. Siswi perempuan sebagai mitra tutur menjawab dengan hanya mengatakan "bisa" (berarti ya) dan "belum" (berarti tidak). 
3) Perintah (requirements)

Tuturan perintah (requirements) mengindikasikan bahwa ketika mengucapkan suatu tuturan, penutur menghendaki mitra tutur untuk melakukan perbuatan. Penutur mengekspresikan keinginan bahwa ujarannya dalam hubungan dengan posisi di atas mitra tutur, merupakan alasan yang cukup bagi mitra tutur untuk melakukan tindakan. Penutur mengekspresikan maksud agar mitra tutur melakukan tindakan (paling tidak sebagian dari) keinginan penutur. Dari hasil analisis jenis tuturan initerdapat sembilan fungsi tuturan perintah yang digunakan oleh pembina upacara, yaitu; fungsi mengarahkan, fungsi menuntut, fungsi menuntut dan melarang, fungsi menuntut dan membatasi, fungsi menuntut dan mensyaratkan, fungsi menuntut dan menginstruksikan, fungsi menginstruksikan, fungsi mengarahkan dan menuntut, dan fungsi menginstruksikan dan melarang. Diantara kesembilan fungsi tersebut, fungsi menuntut adalah tuturan perintah yang paling sering digunakan oleh guru, yaitu sebanyak 4 tuturan.

Tindak tutur requirements dapat dilihat pada tuturan berikut:"Kita sebagai kaum perempuan harus mencontoh dan meniru suri tauladan serta melanjutkan cita-cita Ibu Kartini!”. Tuturan tersebut mengandung maksud bahwa guru memerintahkan siswa untuk mencontoh dan meniru suri tauladan serta melanjutkan cita-cita Ibu Kartini. Tuturan ini juga mengekspresikan bahwa apa yang dituturkan guru (pembina upacara) mengandung alasan yang cukup bagi siswanya untuk segera melakukan tindakan.

\section{4) Larangan (prohibitive)}

Tindak tutur melarang (prohibitive) merupakan suatu tindakan yang menunjukkan bahwa ketika mengucapkan suatu ekspresi penutur melarang mitra tutur untuk melakukan tindakan.Tindak tutur prohibitive dapat dilihat pada tuturan berikut: "Perjuangan kalian masih panjang, jangan saya perempuan saya urusannya nanti dapur, saya ngurus kasur, jangan seperti itu." Tuturan tersebut ditujukan dengan maksud agar siswi perempuan memiliki cita-cita yang tinggi, dari sekedar ibu rumah tangga. Tuturan ini mengekspresikan larangan kepada mitra tutur (siswi perempuan) untuk tidak beranggapan bahwa perjuangannya hanya sebatas di bangku SMA dan berakhir sebagai ibu rumah tangga biasa. Dari hasil analisis jenis tuturan initerdapat dua fungsi tuturan larangan yang digunakan oleh pembina upacara, yaitu; fungsi melarang dan fungsi melarang dan menginstruksikan. Diantara kedua fungsi tersebut, fungsi melarang dan menginstruksikan adalah tuturan larangan yang paling sering digunakan oleh guru, yaitu sebanyak 2 tuturan.

Berdasasarkan tuturan tersebut guru mengekspresikan otoritas kepercayaan bahwa ujarannya menunjukkan alasan yang cukup bagi siswa untuk tidak melakukan tindakan. Pada dasarnya tindakan prohibitive ini merupakan perintah atau suruhan supaya mitra tutur tidak melakukan sesuatu. Pengekspresian larangan tersebut ditandai dengan kata "jangan".

5) Pemberian izin (permissives)

Tindak tutur pemberian izin (permissives) merupakan tindakan yang mengindikasikan bahwa penutur menghendaki mitra tutur untuk melakukan perbuatan. Penutur mengekspresikan kepercayaan bahwa ujarannya dalam hubungannya dengan posisi penutur di atas mitra tutur, membolehkan mitra tutur untuk melakukan tindakan. Dari hasil analisis jenis tuturan initerdapat tiga fungsi tuturan pemberian izin yang digunakan oleh pembina upacara, yaitu; fungsi menganugrahi, fungsi membolehkan, dan fungsi membolehkan dan membatasi. Dari ketiga fungsi tersebut, fungsi menganugrahi dan fungsi membolehkan adalah tuturan pemberian izin yang paling sering digunakan oleh guru, yaitu sebanyak 2 tuturan. 
Tindak tutur permissivesdapat dilihat pada tuturan berikut:"Kamu boleh mengakses informasi yang kamu butuhkan". Tuturan tersebut mengandung maksud bahwa guru membolehkan siswa untuk mengakses informasi yang dibutuhkan melalui teknologi internet. Tuturan ini mengekspresikan kepercayaan untuk memberikan pemberian izin atau membolehkan, sehingga siswa percaya bahwa ujaran guru mengandung alasan yang cukup bagi siswa untuk merasa bebas melakukan sesuatu.

6) Nasihat (advisories)

Tindak tutur nasihat (advisories) adalah tindak ketika mengucapkan suatu ekspresi, penutur menasehati mitra tutur untuk melakukan tindakan. Penutur mengekspresikan kepercayaan bahwa terdapat alasan bagi mitra tutur untuk melakukan tindakan dan penutur mengekspresikan maksud agar mitra tutur mengambil kepercayaan penutur sebagai alasan baginya untuk melakukan tindakan. Dari hasil analisis jenis tuturan initerdapat lima fungsi tuturan nasihat yang digunakan oleh pembina upacara, yaitu; fungsi menasehati dan bertanya, fungsi menasehati dan menuntut, fungsi menasehati dan melarang, fungsi menasehati dan membolehkan, dan fungsi menasehati. Dari kelima fungsi tersebut, fungsi menasehati adalah tuturan nasihat yang paling sering digunakan oleh guru, yaitu sebanyak 13 tuturan.

Tindak tutur advisories dapat dilihat pada tuturan berikut: "Kalian akan memperhatikan sendiri diantara teman kalian, siapa yang punya tujuan, siap yang bersungguh-sungguh ingin berhasil, suatu saat nanti itulah yang akan maju dan mengembangkan dirinya sendiri”. Tuturan tersebut bertujuan memberikan nasihat agar siswa lebih bersungguh-sungguh dalam belajar, jika mereka ingin menjadi orang yang berhasil. Tuturan ini mengekspresikan kepercayaan bahwa ujarannya mengandung maksud yang baik bagi kepentingan siswa.

\section{b. Pembahasan}

Berdasarkan hasil analisis didapatkan bahwa jenis tindak tutur direktif nasihat, terutama fungsi menasehati, merupakan tuturan yang sering digunakan guru (pembina upacara) dalam kegiatan upacara. Jenis tindak tutur ini digunakan karena amanat yang disampaikan ditujukan untuk mendorong perubahan pada sikap dan perilaku (yang selama ini dinilai salah oleh guru) ke arah yang lebih baik. Hal itulah yang menyebabkan bentuk tuturan ini lebih banyak digunakan guru dibandingkan dengan bentuk tindak tutur direktif lainnya.

Hasil temuan dalam penelitian ini berbeda dengan temuan dari penelitian sebelumnya, yaitu; Elmita, dkk (2013); Sumarti (2015); dan Heriyawan (2016). Dari keempat peneliti tersebut, keempatnya menemukan bentuk tindak tutur direktif yang dominan oleh guru adalah bentuk tindak tutur menyuruh. Terdapat perbedaan konteks peristiwa dan peran penutur antara hasil penelitian ini dengan hasil penelitian terdahulu tersebut. Dalam penelitian ini, latar peristiwa tutur terjadi pada saat upacara hari senin tepatnya, dimana penutur (guru) berperan sebagai pembina upacara yang bertugas untuk menyampaikan amanat kepada siswa dan peserta upacara lainnya. Sedangkan latar peristiwa yang melatarbelakangi peristiwa tutur dari keempat hasil penelitian terdahulu tersebut, terjadi pada saat kegiatan belajar mengajar di kelas, dimana penutur (guru) berperan sebagai pengajar (pengendali kelas).

Pada dasarnya juga terdapat kesamaan antara hasil penelitian ini dengan hasil penelitian terdahulu. Kesamaan ini ditunjukkan dari kedudukan guru (penutur) yang lebih tinggi dari siswa (lawan tutur). Dalam hal ini dapat dikatakan bahwa guru (penutur) memegang kontrol atas siswanya untuk melakukan suatu perintah yang diberikan guru (penutur) kepada dirinya. Hal ini dapat dilihat dari dominansi tuturan dari 
guru (penutur) kepada siswa. Adanya dominansi tersebut, menunjukkan bahwa jenis tuturan yang digunakan oleh guru (penutur), baik yang ditemukan dalam penelitian ini maupun penelitian sebelumnya, dipengaruhi oleh faktor semantik kekuasaan sebagaimana teori faktor semantik yang dikemukakan Brown dan Gilman (1968).

Menurut Brown dan Gilman (1968) semantik kekuasaan mengacu kepada otoritas atau wewenang yang dimiliki seseorang atas orang lain. Tingkat kekuasaan berwujud superioritas dari segi umur, pangkat, kekuatan, kebangsawanan, dan lain-lain. Hal ini jelas menunjukkan perbedaan kekuasaan antara guru dan muridnya. Perbedaan kekuasaan inilah yang melandasi mengapa guru (penutur) menggunakan jenis tindak tutur menyuruh yang dimaksudkan untuk membuat siswa melakukan sesuatu sesuai yang diperintahkan guru. Alasan lainnya mengapa guru (penutur) lebih cenderung menggunakan jenis tindak tutur menyuruh dalam kegiatan belajar mengajar, karena siswa di kelas lebih banyak membutuhkan kontrol dan pengawasan dalam bentuk perintah dari guru. Sedangkan bentuk tuturan nasihat sering digunakan guru (penutur) dalam penelitian ini, dikarenakan pesan atau amanat yang disampaikan guru kepada siswa dalam bentuk pidato yang bertujuan memberikan nasihat kepada siswa. Hal itulah yang menyebabkan bentuk ini lebih banyak digunakan guru dibandingkan dengan bentuk tindak tutur direktif lainnya, sebagaimana yang ditemukan dalam penelitian ini.

Bila merujuk pada konteks yang melatarbelakangi tindak tutur direktif guru SMA Negeri 2 Merlung, terdapat 5 faktor yang mempengaruhi beragamnya tindak tutur direktif yang digunakan guru. Kelima faktor tersebut, adalah (1) penutur, (2) lawan tutur, (3) latar, (4) topik atau pesan, dan (5) peristiwa. Untuk faktor penutur, diketahui bahwa setiap penutur (pembina upacara) berasal dari latar belakang budaya dan kebiasaan (perilaku) yang berbeda sehingga hal ini dapat berpotensi mempengaruhi strategi dan bentuk tindak tutur yang digunakan guru. Sementara untuk faktor lawan tutur dan latar, karena komunikasi yang dilakukan bersifat satu arah dan setiap penutur memiliki lawan tutur (siswa) yang sama serta dilakukan pada latar waktu dan tempat yang sama, maka untuk kedua faktor ini diasumsikan tidak begitu mempengaruhi tindak tutur direktif yang digunakan guru.

Konteks kedua yang mempengaruhi tindak tutur direktif adalah lawan tutur. Dalam penelitian ini yang menjadi lawan tutur adalah siswa. Semua penutur memiliki lawan tutur yang sama yaitu siswa kelas X-XII sebanyak 487 orang. Untuk itu, konteks lawan tutur ini tidak dibahas lebih lanjut karena unsurnya sama untuk setiap sumber data. Sama halnya dengan konteks latar. Latar waktu dalam penelitian ini semuanya sama yaitu pagi hari saat pelaksanaan kegiatan upacara hari senin, sehingga juga tidak dipaparkan dalam pembahasan ini. Konteks selanjutnya adalah topik atau pesan. Konteks ini berhubungan dengan topik/pesan yang disampaikan guru (penutur). Satu diantara tiga penutur menyampaikan topik atau materi yang berbeda, sedangkan dua penutur lainnya menyampaikan topik atau materi yang sama. Topik-topik yang mereka sampaikan, adalah; Peringatan Hari Kartini dan Kedisiplinan Belajar.

Konteks terakhir yang mempengaruhi tindak tutur direktif guru dalam kegiatan upacara adalah peristiwa. Peristiwa tutur yang terjadi saat tindak tutur direktif guru berlangsung pada umumnya dalam keadaan tenang. Hal ini disebabkan karena bukan hanya guru yang menyampaikan amanat saja yang menguasai siswa, tetapi karena budaya atau kebiasaan para wali kelas dan guru piket ikut mengamati dan mengawasi mereka selama proses upacara berlangsung. Kebiasaan ini menyebabkan ruang gerak siswa untuk tidak mendengarkan penjelasan guru menjadi 
terbatas. Peraturan yang diterapkan di sekolah pada saat upacara membuat mereka harus mendengarkan amanat yang disampaikan.

Menurut Brown dan Levinson (1987) salah satu faktor yang berpotensi untuk menjatuhkan muka pelaku tutur adalah tindak tutur. Agar tindak tutur tidak menjatuhkan muka pelaku tutur, tindak tutur perlu dilengkapi dengan peranti penyelamat muka yang berupa kesopapanan berbahasa. Menurut Nadar (2009) strategi kesopanan berbahasa adalah cara atau strategi yang secara sadar maupun tidak sadar dipergunakan oleh seorang penutur dalam rangka mengurangi akibat tidak menyenangkan dari tuturannya terhadap lawan tuturnya.

Brown dan Levinson (1987) menjelaskan bahwa pertimbangan yang dijadikan dasar pemilihan strategi kesopanan adalah faktor-faktor (1) jarak sosial antara penutur dan petutur (sosial distance), (2) perbedaan kekuasaan antara penutur (power) dan petutur (speaker), dan (3) status relatif jenis tindak tutur dalam kebudayaan yang bersangkutan (the absolute rankingof imposisition in the particular culture). Dalam kebudayaan tertentu ada bentuk tuturan tertentu yang dianggap santun dan ada pula bentuk tuturan tertentu yang dianggap tidak santun.

Berdasarkan pertimbangan pemilihan strategi kesopanan tersebut, terdapat empat strategi yang digunakan guru (penutur) dalam menyampaikan pidatonya pada kegiatan upacara hari senin di SMA Negeri 2 Merlungsesuai dengan strategi kesopanan yang dikemukakan Brown dan Levinson (1987). Keempat strategi bertutur itu yakni, (1) bertutur terus terang tanpa basa-basi (bald on record); (2) bertutur langsung dengan basabasi kesantunan positif (positive politeness); (3) bertutur terus terang dengan basabasi kesantunan negatif (negative politeness); dan (4) bertutur secara samar-samar atau bertutur tidak langsung (off record).
Strategi bertutur terus terang dengan basabasi kesantunan negatif (negative politeness) adalah yang paling sering digunakan guru (penutur) terutama dalam penggunaan bentuk direktif nasihat. Menurut Brown dan Levinson (1987) kesantunan negatif pada hakikatnya ditujukan terhadap bagaimana memenuhi atau menyelamatkan sebagian muka negatif lawan tutur, yaitu keinginan dasar lawan tutur untuk mempertahankan apa yang dia anggap sebagai wilayah dan keyakinan dirinya. Jadi, pada dasarnya, strategi kesopanan negatif mengandung jaminan dari lawan tutur bahwa penutur mengakui, menghormati, dan seandainya terpaksa melakukan, akan sedikit mungkin melakukan pelanggaran (keinginan muka negatif lawan tutur dan tidak akan mencampuri atau pun melanggar kebebasan bertindak lawan tutur). Dengan demikian dapat dinyatakan bahwa dalam pemilihan strategi kesantunan negatif, guru (penutur) SMA Negeri 2 Merlung, memperhitungkan tingkat keterancaman muka berdasarkan dua hal, yaitu:(1) perbedaan hubungan kekuasaan (power) antara penutur dan petutur dan (2) tingkat hubungan keakraban atau solidaritas antara penutur dan petutur.

Bentuk strategi kesantunan basa-basi negatif yang dominan digunakan dalam tindak tutur direktif guru SMA Negeri 2 Merlung adalah dengan cara menyatakan tindakan mengancam muka negatif lawan tutur sebagai ketentuan sosial yang umum berlaku. Hal ini menerangkan bahwa guru (penutur) berupaya melakukan tindakan penyelamatan muka siswa (lawan tutur) untuk meminimalkan perasaan kurang senang siswa akibat dari tindakan yang kurang menyenangkan (baik dalam ungkapan nasihat, permintaan, pemberian izin, dan perintah), dengan cara melakukan penambahan dan perubahan tuturan sedemikian rupa yang dapat menunjukkan secara jelas kepada siswa (lawan tutur) bahwa keinginan guru (penutur) untuk melakukan tindakan yang kurang menyenangkan tersebut sebenarnya tidak 
dikehendaki oleh guru sendiri, tetapi tindakan ini merupakan suatu hal yang seharusnya memang perlu dilakukan.

Bila dibandingkan dengan hasil penelitian terdahulu terkait dengan strategi kesopanan yang sering digunakan dalam tindak tutur direktif guru, menunjukkan adanya perbedaan dengan hasil penelitian ini. Hasil penelitian Elmita, dkk (2013) dan Erlis, dkk (2014) menunjukkan bahwa strategi kesopanan basa-basi positif merupakan strategi yang paling sering digunakan terutama dalam bentuk tindak tutur direktif menyuruh. Menurut Brown dan Levinson (1987) kesopanan positif merupakan pendekatan yang menorehkan kesan pada muka lawan tutur bahwa pada hal-hal tertentu penutur juga mempunyai keinginan yang sama dengan lawan tutur (yaitu dengan memperlakukannya sebagai anggota kelompok, sahabat, sebagai seseorang yang keinginannya maupun seleranya dikenal dan disukai).

Dalam penelitian ini guru (penutur) SMA Negeri 2 Merlung sangat sedikit menggunakan strategi kesopanan positif dalam tindak tutur direktinya. Hal ini menunjukkan adanya dominansi faktor kekuasan dan jarak di antara guru (penutur) dan siswa (lawan tutur) sehingga sedikit sekali upaya yang dilakukan penutur untuk mendekatkan diri dengan lawan tutur. Adapun bentuk strategi kesantunan basa-basi positif yang dominan digunakan dalam tindak tutur direktif guru SMA Negeri 2 Merlung adalah dengan cara menggunakan bentuk-bentuk identitas kelompok. Hal ini menerangkan bahwa guru (penutur) berupaya melakukan tindakan penyelamatan muka positif siswa (lawan tutur) dengan cara menggunakan penanda sapaaan identitas kelompok sebagai bentuk pengakraban yang dilakukan guru terhadap siswa. Hal ini sejalan dengan apa yang diungkapkan Manaf (2011) dalam tulisannya bahwa cara berperilaku sopan dalam tindaktutur direktif dengan basa-basi pengakraban sama dengan kesopapanan positif yang dimaksudkan oleh Brown dan levinson
(1987). Basa-basi pengakraban dan penganjungan tersebut salah satunya direalisasikan dalam bentuk menggunakan penanda identitas sebagai anggota kelompok yang sama.

\section{Kesimpulan dan Saran}

a. Kesimpulan

Berdasarkan hasil penelitian dan pembahasan yang telah dilakukan dapat diambil kesimpulan sebagai berikut:

1. Jenis tindak tutur direktif yang yang digunakan oleh guru sebagai pembina upacara dalam kegiatan upacara di SMA Negeri 2 Merlung, meliputi: jenis permintaan (requstives), pertanyaan (questions), perintah (requirements), larangan (prohibitive), pemberian izin (permissives), dannasihat (advisories). Dari keenam jenis tindak tutur direktif tersebut, tindak tutur direktif yang cenderung dilakukan guru dalam kegiatan upacara di SMA Negeri 2 Merlung adalah jenis tindak tutur nasihat.

2. Penerapan tindak tutur direktif guru dalam kegiatan upacara di SMA Negeri 2 Merlung direalisasikan dengan menggunakan empat strategi bertutur yakni, (1) bertutur terus terang tanpa basa-basi (bald on record); (2) bertutur langsung dengan basa basi kesantunan positif (positive politeness); (3) bertutur terus terang dengan basa basi kesantunan negatif (negative politeness); dan (4) bertutur secara samar-samar atau bertutur tidak langsung (off record). Dari keempat strategi tersebut, strategi bertutur terus terang dengan basa basi kesantunan negatif (negative politeness) adalah yang paling sering digunakan guru (penutur).

\section{b. Saran}

Merujuk pada hasil dan kesimpulan yang diperoleh dari penelitian ini, maka saran yang dapat diberikan yaitu:

1. Untuk menjaga perasaan siswa agar merasa dicintai dan dihargai, guru 
perlu menggunakan strategi tindak tutur direktif yang dapat memunculkan perasaan positif siswa sehingga penyampaian amanat dalam pidato upacara dapat berlangsung secara kondusif dan efektif. Adapun strategi yang dapat memunculkan perasaan positif siswa (rasa gembira, senang, bangga, dan netral) adalah: (1) tuturan langsung, mengandung unsur pujian, menggunakan sapaan penanda saying dan nama, (4) menghindari penggunaan kata saya dan kamu, (5) melibatkan penutur dan mitra tutur dalam kegiatan, (6) menggunakan penanda permintaan halus, (7) mengandung lelucon, mempertimbangkan keinginan mitra tutur, (9) mengupayakan kesepakatan, dan (10) tuturan tidak langsung. Sementara itu, strategi tindak tutur direktif yang dapat memunculkan perasaan negatif (kesal, takut, dan malu) ialah (1) tuturan tidak langsung bernada menyindir, (2) menyapa dengan kata seru, (3) memperbandingkan, dan (4) ada unsur cacian, sebaiknya penggunaannya dikurangi bahkan bila perlu dihindari.

2. Pihak sekolah diharapkan memilihkan topik atau tema yang akan disampaikan guru (pembina upacara) pada setiap minggunya lebih bervariasi. Pemilihan topik tersebut salah satunya disesuaikan dengan perkembangan siswa dan topik-topik yang akan diterapkan dalam kegitan sehari-hari di masyarakat. Topik yang sesuai dengan perkembangan jiwa siswa akan memotivasi mereka untuk mendengarkan dengan serius. Selain pemilihan topik, pemilihan guru yang akan menyampaikan amanat saat upacara juga perlu diperhatikan oleh kepala sekolah. Hal tersebut mengingat bahwa para siswa yang menjadi mitra tutur sangat banyak sehingga membutuhkan guru yang memang mampu berinteraksi dan mengendalikan siswa dalam jumlah yang banyak dengan cara menyampaikan amanat dengan komunikatif, bermakna, dan menarik.

3. Bagi peneliti selanjutnya, perlu dilakukan kajian terhadap respon warna afektif siswa sebagai efek pesan yang diterima dari penutur, dengan mengunakan strategi tindak tutur direktif yang berbeda. Hal ini dikarenakan belum diketahuinya dalam hasil penelitian ini tentang bagaimana reaksi atau respons peserta upacara sebagai mitra tutur. Hal ini tentu saja membutuhkan sebuah kajian yang empiris.

\section{DAFTAR PUSTAKA}

Brown, Roger dan Albert Gilman. (1968).

ThePronouns of Power and Solidarity. Di dalam Joshua A. Fishman(Ed.). Reading in the Sociology ofLanguage. Hal. 252275. Paris:Mouton.

Brown, Penelope dan Stephen C. Levinson. (1987). Politeness: Some Universalsin Language Usage. Cambridge: University of Cambridge Press.

Chaer, A. dan Agustina, L. (2010). Sosiolinguistik. Jakarta: Rineka Cipta.

Elmita Winda, Ermanto, dan Ellya Ratna. (2013). Tindak Tutur Direktif Guru dalam Proses Belajar Mengajar di TK Nusa Indah Banuaran Padang. Jurnal Pendidikan Bahasa dan Sastra Indonesia, Vol. 1 (2).

Erlis Erina, Novia Juita, dan Irfani Basri. (2014). Tindak Tutur Direktif Guru dalam Kegiatan Muhadarah di MTSN Lubuk Buaya Kota Padang. 
Jurnal Bahasa, Sastra dan Pembelajaran, Vol. 2 (3).

Heriyawan, D.D. (2016). Kesantunan Direktif Tuturan Guru Untuk MemotivasiSiswa Dalam Amanat Pembina Upacara Di SMP N 1Karangdowo. Publikasi Ilmiah, Fakultas Keguruan dan Ilmu Pendidikan, Universitas Muhammadiyah Surakarta.

Keraf, G. (2004). Diksi dan Gaya Bahasa. Jakarta: PT. Gramedia Pustaka Utama.

Manaf, A.N. (2011). Kesopanan Tindak Tutur Menyuruh dalam Bahasa Indonesia. LITERA, Vol. 10 (2).

Nadar, F.X. (2009). Pragmatik dan Penelitian Pragmatik. Yogyakarta: Graha Ilmu.

Saefudin. (2017). Realisasi Strategi Kesantunan dalam Wacana Dakwah (Satu Kajian Pragmatik pada Teks Ceramah Agama dan Khutbah Jum'at). Mimbar Sejarah, Sastra, Budaya, dan Agama, Vol. XXIII (1): 139-157.

Sulistyowati, R.I., Harun Joko Prayitno, dan Yakub Nasucha. (2013). Perilaku Tindak Tutur Ustad dalam Pengajian: Kajian Sosiopragmatik dengan Pendekatan Bilingual. Jurnal Penelitian Humaniora, Vol. XIV (1): 25-40.

Sumarti. (2015). Strategi Tindak Tutur Direktif Gurudan Respons warna Afektif Siswa(Kajian Pragmatik dan Implikasinya dalam Pembelajaran Bahasa Indonesia di SMP). Artikel Penelitian, FKIP Universitas Lampung. 